Оригинални научни рад

УДК 821.133.1.09-2

Примљен: 28. марта 2021.

Прихваћен: 4. априла 2021.

Никола Р. Бјелић ${ }^{1}$

https://doi.org/10.46630/phm.13.2021.05

Универзитет у Нишу

Филозофски факултет ${ }^{2}$

Департман за француски језик и књижевност

\title{
ИНТЕРТЕКСТУАЛНЕ ВЕЗЕ ИЗМЕЪУ КОМАДА НОЋ У ВАЛОЊИ ЕРИК-ЕМАНУЕЛА ШМИТА И МОЛИЈЕРОВОГ ДОН ЖУАНА
}

У раду се бавимо најпознатијом модерном митском личношћу, Дон Жуаном, у првом комаду савременог француског писца Ерик-Емануела Шмита, Ноћ у Валоюи, из 1989.

Циљ рада је да покажемо трансформацију главног јунака у Шмитовој интерпретацији овог мита насталог у бароку. Кроз интертекстуално ишчитавање Шмитовог комада са најпознатијим, Молијеровим (Дон Жуан, 1665), утврдићемо које су додирне тачке, а које разлике између ова два позоришна текста. Покушаћемо да докажемо тезу да је Шмитов комад више класичарски од Молијеровог, који, по својим карактеристикама, више припада епохи барока.

Осим тога, показаћемо и релације Шмитовог комада са неким новијим реинтерпретацијама овог мита.

Клучне речи: Молијер, Шмит, Дон Жуан, класицизам, три јединства, мит, реинтерпретација, интертекстуалност

1. Увод

Написан на крају 20. века, први позоришни комад савременог француског драматичара Ерик-Емануела Шмита (Éric-Emmanuel Schmitt, 1960), Hoћ у Валоюи (La Nuit de Valognes, 1989, друга верзија 2006), чија је премијера била 17. септембра 1991. у позоришту Еспас 44 у Нанту $^{3}$ и 4. октобра исте године у Позоришту Шанзелизе у Паризу (ŠMIT 2006: 126), представља нову варијацију чувеног мита о Дон Жуану. Ова верзија 1 nikola.bjelic@filfak.ni.ac.rs

2 Овај рад је настао у оквиру међународног научног пројекта Романистика и словенски језици, кюижевности и културе у контакту и дисконтакту (по 1001-13-01) који делом финансирају Универзитетска агенција за франкофонију и Амбасада Француске у Србији.

3 Espace 44 
приказује суђење које Дон Жуану спроводе његових пет бивших љубавница (војвоткиња де Вобрикур, грофица де ла Рош-Пике, госпођица де ла Тренгл, редовница Хортензија де Отклер и госпођа Касен $)^{4}$ и казну које су му оне намениле.

Мит о Дон Жуану је рођен у историјском добу, па се тако зна датум његовог настанка. Он је рођен на југу, у Шпанији, у доба Ренесансе. Творац прве верзије, која ће касније послужити као подстрек и предложак другим верзијама, јесте чувени шпански писац Тирсо де Молина (Tirso de Molina, 1583-1648). Легенда о заводнику се први пут појавила у његовом комаду Севиљски заводник и Камени гост (Burlador de Sevilla y convidado de piedra) из 1630. године.

Комадом Ноћ у Валоюи почиње Шмитова позоришна и књижевна каријера. Овај комад на најбољи начин преноси његову младалачку љубав према позоришту (в. BJELIĆ 2016а), његову наклоност према музици (в. BJELIĆ 2016c) и окренутост уметности класицизма, па се у њему лако могу пронаћи и пратити реминисценције и интертекстуалне везе и односи са делима која му претходе.

Ноћ y Валоюи представља спој старог и новог, класичног и модерног, то је пример „оне жеље да се створи ново полазећи од нагомилавања успомена, поцепаних скица, заборављених рукописа“ (LAMEZON 2006: 7). ${ }^{5}$ Шмитова верзија Дон Жуановог лика садржи у себи истовремено „читаво књижевно наслеђе овог секуларног мита, али и жељу да се раскине са његовом прошлошћу“ (LAMEZON 2006: 7). Тај комад, који доноси ауторову личну „визију Дон Жуана“ (ŠMIT 2005), представља нову, потпуно радикалну реинтерпретацију овог мита, у којој се појављују теме као што су љубав, секс, Бог, судбина, којима ће се Шмит посветити у својим каснијим делима (в. BJELIĆ 2009).

Заједно са Сервантесовим Дон Кихотом, који је настао у истом књижевном раздобљу у Шпанији (1605-1615), Дон Жуан представља један специфичан модерни мит, односно мит модерних времена. Та два мита су митови „преврата и уништења“ (LAMEZON 2006: 16). Није нимало чудно што су оба ова мита настала баш у католичкој Шпанији, на самом почетку XVII века, управо када је она излазила из свог Златног доба. Дон Жуанов негаторски став према свим вредностима показује његов провокаторски дух. Ниједна друга држава није у тој мери као Шпанија осетила долазак модерних времена. За мање од једног века она је прешла пут од најјаче државе Запада, која је кренула у освајања и колонизацију који су јој донели углед и богатство, до доба декаденције и опадања које

4 La Duchesse de Vaubricourt, La Comtesse de la Roche-Piquet, Mademoiselle de la Tringle, Hortense de Hauteclaire, Dite La Religieuse, Madame Cassin.

5 Сви преводи у чланку, осим ако није другачије наведено, наши су. 
ју је сврстало међу слабије државе Запада.

Управо у то и такво доба рађа се Дон Жуан, прецизније мит о њему, „у том стицају околности произашлом из победничког католицизма, из нестварне потраге за другим местом, и из мучног искуства о несталности људске среће“ (LAMEZON 2006: 16). Све то даје основне црте изворном миту, које ће се касније преносити, а то су „борбени атеизам, несмирена потреба за новином и позоришни смисао за нихилизам“ (LAMEZON 2006: 17). Из свега тога се да̂ закључити да је Дон Жуан барокна творевина.

Међутим, главну улогу у европском ширењу и интернационализацији мита одиграће Француска. Нарочито важну улогу имаће Молијеров комад Дон Жуан или Камени гост (Molière, Dom Juan ou le festin de pierre, 1665), писан у прози, али и верзија Томе Корнеја (Thomas Corneille) из 1677, писана у стиху. Управо ће Корнејева верзија довести до тога да отпочне популаризација овог мита широм Европе. Мит о Дон Жуану усвојиле су и адаптирале све европске културе, тако да је број верзија и реинтерпретација веома тешко одредити. Свака земља и свака епоха желеле су да присвоје овај мит и да дају своју варијанту: Немачка (Хофман, Грабе, Ленау, Моцарт, Брехт, Хорват, Фриш, Хандке), Енглеска (Бајрон, Шо), Данска (Хајберг, Киркегор), Шпанија (Замора, Сориља, Баљестер), Италија (Голдони, Чезарео), Русија (Пушкин, Толстој), Шведска (Алмквист), а нарочито Француска (Молијер, Тома Корнеј, Доримон, Розимон, Дима, Мисе, Мериме, Готје, Бодлер, Д’Орвији, Батај, Монтерлан, Ростан итд.). То је књижевно наслеђе које је било на располагању Ерик-Емануелу Шмиту у тренутку када је одлучио да да̂ своју верзију и реинтерпретацију овог мита (в. RUSE 1995). Иако је Шмитова верзија потпуно нова и другачија у односу на претходне, постоји велики број интертекстуалних веза и односа са њима, нарочито са Молијеровом, тако да ћемо се њом подробније бавити у овом раду.

\section{2. Структура Молијеровог и Шмитовог комада}

Молијеров комад је имао премијеру у фебруару 1665. године и доживео је велики успех, али је након пет седмица извођења скинут са репертоара (в. MILAČIĆ 1973). Његов комад је обележен барокним духом свога претходника. Молијеров Дон Жуан писан је у пет чинова у прози, без поштовања правила класицизма коме је припадао, нарочито правила о три јединства (места, времена и радње), без веће везе између чинова, са мешавином жанрова. Дуго се сматрало да је Молијер то урадио због брзине приликом писања овог комада, који је настао у време када је његов претходни комад Тартиб (Le Tartuffe) забрањен за извођење (1664), из потребе да се попуни репертоар његовог позоришта. Међутим, опште- 
прихваћено мишљење данас је да је Молијер све то урадио промишљено, с намером да покаже излишност и бесмисленост свих правила, као и да још једном истакне како је једино правило, које се може сматрати валидним, правило „допасти се“б (MOLIJER 1975b: 209, 210) и насмејати, jep је „веома тешко насмејати људе развијеног укуса“" (MOLIJER 1975b: 208). Ако се то постигне без поштовања правила која намеће класицизам, онда су она непотребна и сувишна. Дон Жуаном Молијер то и показује. За своју комедију Молијер бира савремени позоришни жанр „pièce à machine“, који му даје велику формалну и генеричку слободу. Овај жанр Молијеру одговара за природу теме коју је преузео од претходника, којој уопште не одговара структура традиционалне комедије. Једино му тај жанр омогућује да уведе камену статуу која се креће, појављивање утваре $(\mathrm{V}$ чин), муњу $(\mathrm{V})$ и ишчезавање јунака - елементе који потпуно нарушавају правило веродостојности које је класицизам прописивао, што су му савременици и замерали (LAMEZON 2006: 25-26). Увођење чудесног и велика разноликост перипетија у причи о Дон Жуану упућују на барокну структуру овог дела, коју је Молијер преузео од Тирса де Молине (в. MOLINA 2000).

Шмитов комад Ноћ у Валоюи препун је алузија и реминисценција на Молијеров комад. Велики је број експлицитних и имплицитних референци на Молијеровог Дон Жуана, али структура Шмитовог комада је потпуно различита. Шмит избегава увођење чудесног у композицији свог комада. Његово дело је изразито „правилније“ од Молијеровог у смислу очувања класичних правила, и тиме је драматуршки ближе класичној комедији. Ако бисмо се послужили речима Лубомира Долежела при анализи Куцијевог романа Фо наспрам Дефоовог Робинсона Крусоа, могли бисмо да кажемо да „у стандардној семантичкој обради текста, читалац“ Ноћ у Валоюи „реконструише фикционални свет“ Молијеровог комада, „активирајући при том и фикционалну енциклопедију“ Дон Жуaна „као когнитивну позадину“ (DOLEŽEL 2008: 228-229).

Иако је Шмитова драма написана у три чина, и код њега и код Молијера радња се одвија кроз 28 сцена. Међутим, код Шмита су испоштована правила о три јединства ${ }^{8}:$ јединство времена, јединство места и јединство радње, што код Молијера није случај.

За разлику од већине осталих комада, у Дон Жуану Молијер није испоштовао јединство времена. Радња комада траје отприлике 36 сати код њега, а не један дан. Шмитов комад има чврсту конструкцију и веома

6 «DORANTE : Je dis bien que le grand art est de plaire»

7 « c'est une chose étrange que celle de faire rire les honnêtes gens "

8 Та правила је дефинисао Боало у Песничкој уметности, преузевши их од Аристотела из Поетике. Детаљније о њима у: RUBIN 2006: 31-41. 
прецизне одреднице у дидаскалијама, које нам омогућују да анализирамо његову унутрашњу структуру у светлу класичних правила. Сам наслов сугерише да се радња комада одвија чак краће од једног дана, током само једне олујне ноћи негде у провинцији Француске. Дидаскалије доносе детаље историјског оквира. У првој се недвосмислено наводи да се радња дешава средином XVIII века у једном замку, једне хладне ноћи без месеца, са црним и ниским небом, док у последњој видимо како ће „дан [...] полако испунити сцену“, али како „још није у потпуности свануло“ (ŠMIT 2009: III чин, сцена 16, 112-113).

Шмитов комад је, дакле, прецизно временски и историјски одређен и ситуиран, јер Шмит „инсистира на важности историјске, политичке и друштвене условљености своје радње“ (LAMEZON 2006: 27). Комад се одиграва у свега неколико сати. Временски прелази између чинова су готово неприметни, јер само неколико сати дели почетак I чина од III чина, који почиње нешто пре зоре. Дакле, јединство времена је у потпуности испоштовано, јер мање од 12 сати ће проћи од доласка Грофице у Војвоткињин замак до Дон Жуановог одласка из њега.

Ни јединство места у Молијеровом комаду није испоштовано. Свих пет чинова Молијеровог Дон Жуана одвија се на другом месту: I чин се дешава у дворцу, радња II чина одвија се на пољу уз морску обалу, III чин дешава се у шуми, IV чин у Дон Жуановом стану, a V на пољу. Радња се одиграва на Сицилији. Анализирајући простор у Молијеровом комаду, Мирјана Миочиновић наводи да је Молијер имао веома тежак задатак „да постигне континуитет, илузију континуитета, са јунаком кога дословно 'не држи место"“ (2008: 44). Свих пет различитих простора у Молијеровом комаду везани су за топос града и показују „могућни радијус јунаковог кретања“" (MIOČINOVIĆ 2008: 44), што омогућује писцу да „сачува утисак да се јединства времена и места поштују“ (MIOČINOVIĆ 2008: 44-45). За разлику од тога, сва три чина Шмитовог комада одигравају се „на истом месту““10 (ŠMIT 2009: 54, 81), како је наговештено на почетку сваког, а то је салон у дворцу Војвоткиње де Вобрикур, у Нормандији, у близини града Валоње. Нема промене декора. Реч је о старинском салону, са старим намештајем прекривеним заштитним платнима, прашином и паучином. У дну салона налази се степениште којим се ликови спуштају или пењу приликом уласка и изласка са сцене. На сцени су осим тога и једна врата која воде у „салу за суђење“"11 (ŠMIT 2009: I, 7, 53) у којој се одвија невидљиви део суђења, као и библиотека иза које се налази

\footnotetext{
9 "le jour [...] envahira progressivement la scène ", "Le jour n'est pas encore tout à fait levé".

10 «même lieu»

11 «la salle du procès»
} 
„тајни пролаз“12 (ك̌MIT 2009: II, 4, 78) у ком се крије војвоткиња приликом прислушкивања разговора између Дон Жуана и Анжелике (ŠMIT 2009: II, 4, 78-79). Реч је о јединственом, непромењеном декору, који представља унутрашњи простор, док је спољни свет евоциран увођењем звучних елемената (олуја, муња) или алузијом самих ликова на кишу и хладноћу које владају напољу.

Међутим, III чин уводи игру позоришта у позоришту (преузету из поетике барока), која донекле нарушава јединство времена и места. $4,6,7,8,9,10$. и 12. сцена III чина приказују флешбек сцене (повратак у прошлост), које нас враћају на догађаје од пре неколико месеци, тачније на догађај који се збио пет месеци и двадесет осам дана пре ноћи суђења, када је Дон Жуан срео Анжеликиног брата, витеза де Шифрвила. У 4. сцени приказује се једно неодређено мрачно место, сцене 6-10. приказују крчму Три лисияа, 11. сцена приказује „мрачну собу“ у којој се налази „један велики кревет прекривен белим“"13 (ŠMIT 2009: III, 11, 100), док се у 12. сцени прелази на једно „празно поље једног јутра“"14 (ŠMIT 2009: III, 12, 102). Свака од ових флешбек сцена пропраћена је променом јачине светлости и отварањем декора у дну сцене. Ипак, ни у једном тренутку се не склања, не скрива нити мења постојећи декор салона. Он је у свим тим сценама присутан, и у њему се налазе остали ликови који прате дешавања у овим сценама. Реч је о споредној радњи која се препричава и објашњава ликовима како би им се осветлиле промене у Дон Жуановом карактеру, па те сцене позоришта у позоришту не представљају у правом смислу нарушавање јединства времена, места и радње. То „приповедање у огледалу“ (DELENBAH 1977) омогућује да се „избегну правила јединства времена и места тако да изгледа као да су испоштована“ (LAMEZON 2006: 29).

Молијер не поштује ни правило о јединству радње. Радња његовог комада није јединствена. Једино јединство које повезује радњу у његовом комаду јесте стално присуство Дон Жуана на сцени, као и опасности којима је он константно изложен. Том „сталном присутношћу једног иначе покретљивог јунака (од укупно двадесет осам сцена, Дон Жуан се не појављује у само две) сачувано је не само јединство, већ и континуитет радње, и то континуитет који сведочи о хитњи човека који је гоюен а не вођен“ (LAMEZON 2006: 29). Шмитов комад чува и ово правило. Радња у њему је јединствена, а одвија се на два нивоа. Први ниво представља суђење Дон Жуану. Други ниво односи се само на III чин, и реч је о уметнутој причи о витезу де Шифрвилу и његовом сусрету са Дон Жуаном. Ове

12 "passage secret»

13 "chambre sombre", " un grand lit couvert de blanc"

14 «champ nu au matin» 
две радње повезује Зганарелов глас „из офа“15 (SCHMITT 2009: III, сцене $7,8,9,10,96-100)$, тј. иза кулиса, ${ }^{16}$ који приповеда причу о догађају који се десио пре пет месеци и двадесет осам дана, када су се Дон Жуан и Витез срели. Зганарелов глас отвара сваку од флешбек сцена, у којима се приповеда ова епизода. Захваљујући овом проседеу „приповедања у огледалу“, односно позоришта у позоришту, Шмит избегава дуге монологе и нарације који би могли да произведу досаду у гледалишту и даје живост радњи комада, а да притом не нарушава драмско јединство нити прекида приповедну нит. Циљ овог проседеа и ових флешбек сцена одговара основном задатку који, након поновног сусрета са Дон Жуаном у I чину, бивше љубавнице себи постављају: не да осуде Дон Жуана да се ожени и поправи, већ да разумеју разлоге дубоке и корените трансформације овог лика коју су уочиле већ приликом његовог првог појављивања у замку. Без ових кратких уплива прошлости у садашњост радње комад би изгледао потпуно другачије, јер управо оне су кључне за развијање интриге и за расплет који ће уследити (LAMEZON 2006: 29). Дакле, ове две радње нису различите, већ комплементарне. Оне се допуњују и објашњавају.

Сам Шмит дефинише драматуршки рад као рад који у приличној мери мора да трпи правила и принуде:

трајање представе одређује границе дела, логика ситуација организује сцене, живи дијалог омогућује да се пише а да се избегава сувишно, стрепња да се досади гледаоцу чини да се смањује број страна, дефинитивно одсуство света и природе заједно са бескорисношћу њиховог описивања усредсређују на људско, а потреба да се да̂ добра подела сваком глумцу одређује начин изражавања. Драматург наликује композитору квартета: његова камерна музика захтева јасну мисао, прецизну конструкцију, а забрањује нарцисоидност. ${ }^{17}$ (LAMEZON 2006: 26-27)

Управо ови захтеви намећу писцу рад на сопственом тексту и објашњавају зашто је Шмит компоновао свој комад на овако строг начин. ${ }^{18}$ Сви ови захтеви блиски су поетици класицизма, њеном строгом 15 «SGANARELLE OFF ».

16 Израз „из офа“ се колоквијално користи у позоришту да означи ситуацију када се неки од ликова налази иза сцене и говори иза кулиса, односно када се чује његов глас, али се он не види.

17 « la durée d’une représentation fixe les limites d'une œuvre, la logique des situations organise les scènes, le dialogue vivant permet d'écrire tout en prévenant de trop écrire, l'angoisse d'ennuyer le spectateur fait couper dans les pages, l'absence définitive du monde et de la nature jointe à l'inutilité de les décrire concentre sur l'humain, la nécessite de donner une bonne partition à chaque acteur précise le trait. Le dramaturge rejoint le compositeur de quatuor : sa musique de chambre exige une pensée claire, une construction rigoureuse et interdit le narcissisme. »

18 То објашњава и чињеницу да је Шмит 2005. прерадио III чин комада, написавши 
поштовању правила и законитости приликом писања. У том смислу можемо рећи да се Ноћ у Валоюи налази на трагу највећег комедиографа француске књижевности. Али, Шмитово писање, које је „без миметичке претензије и жеље за пародијом Молијеровог модела“, „сведочи о истој непрестаној потрази за разноврсношћу: разноврсношћу тонова, регистара, лексичких поља, реторичких проседеа, који обогаћују структурну форму комичног“ (LAMEZON 2006: 41-42).

\section{3. Шмитов и Молијеров Дон Жуан у дијалогу}

Шмит веома спретно варира тонове и контрасте. Ипак, пошто се радња одиграва у XVIII веку, говор и тон највише одговарају овом раздобљу. На Молијеров модел указују и неке позајмице из његовог комада, али пре свега Зганарелов анахрони начин изражавања, који је у супротности са тоном целог комада. Својом анахроношћу и застарелим изразима које употребљава, Шмитов Зганарел упућује на Молијеровог Зганарела.

Радња Шмитовог комада се не одвија у Шпанији у XVII веку, као што је случај код Молијера, већ у једном замку у Нормандији, једне олујне ноћи, средином XVIII века, у који војвоткиња де Вобрикур позива четири бивше Дон Жуанове жртве, које је овај либертен завео, а потом напустио. Њена идеја је да ове бивше жртве организују суђење Дон Жуану, а казна за његова злодела би била да се он обавеже да изабере између две могућности: или да се поправи, тако што ће се „оженити једном од својих жртава, бити јој веран и учинити је срећном“19 (ŠMIT 2009: I, 5, 30) или да заврши у затвору. Оно што оне никако нису очекивале и што их изненађује јесте чињеница да ће Дон Жуан ту казну прихватити без икаквог оклевања. Зато ће суђење променити ток и главни задатак ће бити да оне у току ноћи покушају да сазнају разлоге за такав неочекивани Дон Жуанов поступак.

Интрига у комаду Ноћ у Валоюи потпуно је, дакле, другачија од интриге из Молијеровог Дон Жуана или Моцартовог Дон Бованија. Дон Жуан каквог приказује Шмит није више ватрени младић, жељан освајања, који, након што освајање успе, оставља освојену жену само да би кренуо у освајање других, какви су сви Дон Жуани који му претходе, већ је јунак на прагу старости. Шмит то питање старења јунака обрађује „на оригиналан начин, јер је оно стављено у однос са питањем опстајања мита и опстанка Дон Жуана као херојске личности“ (GURNE 2013b: 261).

Молијеров Дон Жуан је заводник, чији је једини циљ освајање. Он је незасит и ниједан број заведених жена га не задовољава. Он дефинитивну верзију која је штампана 2006.

19 «LA DUCHESSE : En épousant une de ses victimes, en lui étant fidèle, et en la rendant heureuse. » 
стално жели још и више. У једном тренутку, Молијеров Дон Жуан каже свом слуги Зганарелу: „Да, вере ми, треба се поправити. Живећемо овако још двадесет или тридесет година, а онда ћемо помишљати и на себе“"20 (MOLIJER 1976: IV чин, сцена 11, ${ }^{21}$ 196). Дакле, Молијеров Дон Жуан приказује јунака у пуној снази у време његових најплоднијих освајачких дана.

У својој верзији, осим што помера радњу из XVII у XVIII век, век либертена и борбе за слободе, који је предмет његових најширих интересовања, 22 Ерик-Емануел Шмит мења и године јунака, приказујући, у неку руку, шта је било касније, односно након општепознате приче о Дон Жуану. Он приказује Дон Жуана управо тамо где га је Молијер оставио. Молијеров Дон Жуан жели још двадесет-тридесет година заводничког живота, а после ће видети шта даље. Шмит управо приказује шта је било након тих тридесетак година.

Шмитов Дон Жуан је престао да осваја жене пре пет месеци и двадесет осам дана, како је забележено у Зганареловој бележници. Он стари пред нашим очима, тако да га војвоткиња сматра варалицом:

Погледајте та рамена која се повијају - а под теретом чега? Дон Жуана ништа не притиска. Погледајте његов поглед утонуо у мисли: рекло би се да је реч о човеку који се сећа, али Дон Жуан нема памћење. Погледајте како време почиње да тка своје платно на његовом лицу, те мале боре [...]. Дон Жуан није потчињен законима времена. ${ }^{23}$ (ŠMIT 2009: III, 3, 87)

Уместо да га на вечеру позове Командантова статуа, као код Молијера, њега је позвала једна жива жена, а суди му скуп од пет његових бивших љубавница. Код Шмита, Дон Жуан на крају не умире, већ се поново рађа тако што усваја лекцију којој га је подучио витез де Шифрвил сопственим жртвовањем (в. GURNE 2013a: 531). Ипак, Шмит у више наврата директно упућује на Молијеров комад, како би контрастирао ова два дела. Молијеров комад почиње Зганареловом похвалом дувана (чин

20 «DOM JUAN : Oui, ma foi ! il faut s'amender; encore vingt ou trente ans de cette vie-ci, et puis nous songerons à nous. » (MOLIJER 1975a: IV, 7, 306)

21 У Лесковчевом преводу, подела на сцене се разликује од оригиналне. Кад год неки лик остане сам, Лесковац је то одвајао у посебну сцену, што код Молијера није увек случај. Тако је ово код Молијера 7. сцена (MOLIJER 1975a: 306), а код Лесковца 11. сцена (в. MOLIJER 1993: 196). Киш је у свом преводу испоштовао оригиналну поделу на сцене. 22 Шмит се бавио XVIII веком, нарочито Дидроом, у својој докторској дисертацији из филозофије, а Дидроу је посветио и позоришни комад Либертен. (в. BJELIĆ 2016b)

23 «LA DUCHESSE : Observez ces épaules qui s'arrondissent - sous le poids de quoi ? rien ne pèse sur le vrai Don Juan. Voyez ce regard perdu dans des pensées : on dirait un homme qui se souvient, or Don Juan n'a pas de mémoire. Voyez le temps qui commence à tisser sa toile sur son visage, ces petits fils de rides [...] Don Juan n'est pas soumis aux lois du temps. » 
I, сцена 1). И Шмитов Зганарел се први пут појављује на сцени пушећи своју лулу (ŠMIT 2009: II, 1, 54; II, 2, 55), што је директна алузија на Молијерову комедију. У првој појави на сцени, Шмитов Дон Жуан евоцира свој пролазак преко гробља, описујући посебно статуу војвоткињиног чукундеде, која има „непомичан поглед, одбојно држање, високо чело, с руком на мачу“ ${ }^{24}$ (ŠMIT 2009: I, 6, 36). У сцени флешбека, Зганарел се препада пред статуом која се помера. Статуа пружа руку Дон Жуану, који је прихвата. Али уместо да одведе Дон Жуана у пакао, статуа - витез де Шифрвил који се забављао изигравајући аутомат - прасне у смех и позове га на пиће (ŠMIT 2009: III, 4, 92). Појава статуе овде, иако није реч о правој статуи, нема улогу освете као у миту, јер витез де Шифрвил глуми аутомат пре него што умре, тако да нема за шта да се свети. Дакле, статуа код Шмита не долази на крају да реши конфликт, већ се појављује на почетку и узрокује све остале догађаје, тако да се може говорити „о инверзији традиционалне схеме и, нарочито, о потпуној промени хронологије између епизода, подвлачећи вољу да се игра са митом и интертекстуалношћу“ (GURNE 2013a: 807).

Када Шмитов Дон Жуан пита свог слугу зашто прати „једног тако лошег господара, највећег зликовца кога је икада земља носила, бесомучника, псето, ђавола, Турчина, јеретика“"25 (ŠMIT 2009: II, 2, 57), његова реплика је цитат, односно дословно преузета реченица коју Молијеров Зганарел говори Елвирином слуги Гусману: „да је мој господар, Дон Жуан, највећи зликовац кога је икада земља носила, бесомучник, псето, Ђаво ${ }^{26}$, Турчин, јеретик“"27 (MOLIJER 1976: I, 1, 119). Док се Молијеров комад завршава повицима Зганарела који види како његова плата неповратно одлази са смрћу његовог господара (MOLIJER 1993: V, 6, ${ }^{28} 83$ : „Моја плата! Оде мени моја плата! ${ }^{\left({ }_{22}\right)},{ }^{30}$ код Шмита Дон Жуан на растанку 24 « regard fixe, pose farouche, front haut, la main sur la glaive »

25 « Pourquoi attaches-tu tes pas à un maître aussi mauvais, le plus grand scélérat que la terre ait porté, un enragé, un chien, un diable, un Turc, un hérétique ?»

26 Реч Ђаво је у Лесковчевом преводу изостављена.

27 «que tu vois en Dom Juan, mon maître, le plus grand scélérat que la terre ait jamais porté, un enragé, un chien, un diable, un Turc, un hérétique, qui ne croit ni ciel, ni enfer, ni loup-garou, qui passe cette vie en véritable bête brute, un pourceau d'Épicure, un vrai Sardanapale, qui ferme loreille à toutes les remontrances chrétiennes quon lui peut faire, et traite de billevesées tout ce que nous croyons. » (MOLIJER 1975a: I, 1, 286)

28 У Лесковчевом преводу, последња реплика $\mathrm{V}$ чина одвојена је у посебну, 7. сцену, јер Зганарел тад остаје сам на сцени (в. MOLIJER 1993: 210). Код Киша је то и даље 6. сцена, jep је тако и у оригиналном тексту на француском. (в. MOLIJER 1993: 83 и MOLIJER 1975a: 310)

29 У Кишовом преводу (MOLIJER 1993, 83). У Лесковчевом преводу (MOLIJER 1976: 210) плата се не помиње.

30 «SGANARELLE : Ah! mes gages! mes gages!»(MOLIJER 1975a: V, 6, 310) 
Зганарелу стави нешто у руку. Када нестане у даљини, Зганарел седне на ивицу сцене и зајеца, јер му је Дон Жуан платио за сав његов рад („Моја плата, Госпођо... Дао ми је моју плату!“”з, ŠMIT 2009: III, 16, 114), чиме се комад завршава, у потпуној супротности од Молијеровог, зором и рађањем, а не смрћу и паклом. Зганарелова реплика и осећање могу се овде двоструко тумачити: он је задовољан што је добио плату, али и жали што Дон Жуан ког је он познавао (и чак створио) више не постоји.

Код Шмита женски ликови су бројнији и важнији. Док у Молијеровом комаду, у 1. сцени I чина Зганарел даје податке о свом господару и његов опис, код Шмита је, како примећује Орелија Гурне (2013а: 555), ситуација потпуно обрнута и та улога поверена је једној жени, војвоткињи де Вобрикур, бившој Дон Жуановој жртви, која чак говори Зганарелу да слабо познаје свог господара (ŠMIT 2009: III, 3, 87). Шмитов Зганарел много више личи на Молијеровог Зганарела, него што Шмитов Дон Жуан наликује Молијеровом. Када се Дон Жуанове жртве жале што се овај променио и што више није заводник као пре, што је остарио, Зганарел га брани. Он ипак најбоље познаје свог господара и воли га таквог какав је, не прихватајући „идеју да се он може променити, чак и на боље“ (GURNE 2013a: 592). Зганарел је експерт за Дон Жуана, коме се сви и обраћају за податке, он је хроничар, односно „историчар“"з2 (ŠMIT 2009: II, 2, 61) који изјављује самоуверено: „Кад Дон Жуан не би постојао, ја бих га могао измислити“"з3 (ŠMIT 2009: III, 3, 89), што је на комичан начин парафразирана чувена Волтерова реченица о постојању Бога, ${ }^{34}$ настала управо у време дешавања радње Шмитовог комада. Шмит даје Зганарелу велику важност, будући да је, као у већини верзија, управо Зганарел одговоран за Дон Жуанову репутацију, јер он је тај који, без знања свога господара, има бележницу у коју уписује његова освајања и после их чита другима. Пошто „Дон Жуан нема памћење“ ${ }_{35}$ (ŠMIT 2009: III, 3, 87), Зганарел преузима ту улогу на себе, он постаје његово памћење и савест. Управо зато му војвоткиња јасно ставља до знања да он најбоље зна да се Дон Жуан променио и када се то десило, али он ту промену неће да призна пред другима. Због тога Шмитов Зганарел има слободу да врло често веома слободно улази у расправе са својим господарем. У 2. сцени II чина постоји инверзија односа господар - слуга, када Зганарел показује своју доминацију над господаром, прекидајући његову тек започету реплику

\footnotetext{
31 « Mes gages, Madame, mes gages... Il me les a donnés!»

32 « Je suis un historien sérieux. »

33 «si Don Juan n'existait pas, j’aurais pu l'inventer. »

34 «Si Dieu n'existait pas, il faudrait l'inventer. »

35 «Don Juan n’a pas de mémoire.»
} 
и постављајући му питање „зашто бежати““з (ŠMIT 2009: II, 2, 61). Он му тиме ставља до знања да ће га бранити пред свима, али да пред њим он мора бити оно што заиста јесте.

Шмитов поступак се разликује од Молијеровог поступка у елаборацији мистерије. Ако се дуж целог Молијеровог комада може поставити питање: „Да ли ће се Дон Жуан покајати?“, ипак тренутак напетости не представља битан елемент текста. Супротно томе, Шмитов комад поставља читав низ питања на која се постепено разоткривају одговори: Чији је портрет (скривен од публике) који у I чину толико узнемирује војвоткињине гошће? Зашто Дон Жуан пребледи на спомен имена Шифрвил? Из којих разлога он прихвата да се ожени Анжеликом, чак и ако је не воли? Зашто обећава да ће јој остати веран, а даје јој слободу да она буде у вези са другим мушкарцима? Зашто је престао са освајањима пре пет месеци и двадесет осам дана, а притом наставио да игра улогу освајача? Зашто се променио, до те мере да је постао човечан?

Постепено разоткривање праћено је замкама и једним неочекиваним обртом. На почетку III чина војвоткиња је говорила о једном мртвацу, за кога сви помисле да је Дон Жуан („он, који је био тако леп... повучен, скрхан, изнурен... и та крв која се већ згрушала на његовој слепоочници... [...] изгледа да је скочио кроз прозор своје собе, и смрскао се о земљу...", ${ }^{37}$ ŠMIT 2009: III, 1, 81), док се најзад не схвати да је реч о њеном пауну. Остарели паун је очигледно метафорички повезан са Дон Жуаном. Како знамо да је паун животиња која би најбоље могла да симболизује барок, својом несталношћу, разметљивошћу, гиздавошћу (в. РУСЕ 1998), тако можемо повезати и с те стране феномен донжуанизма са бароком, у коме је мит и настао. Паун је велика и прелепа птица, али птица која не може да лети, и која је везана за замљу. На исти начин, Дон Жуан је заводник, који је опседнут освајањем и љубављу, али који не уме да воли. Паунова смрт, која је можда и самоубиство, симболизује у Шмитовом комаду смрт Дон Жуана као заводника. Две сцене после тога, војвоткиња објављује обрт наговештавајући да се процес не може одржати пошто недостаје оптужени: „Овај човек није Дон Жуан. Овај човек је варалица" ${ }^{38}$ (ŠMIT 2009: III, 3, 87). Управо од тог тренутка сазнајемо да Дон Жуан више није Дон Жуан, јер „Дон Жуан не подлеже законима времена“"39 (ŠMIT 2009: III, 3, 87).

36 «Pourquoi fuir?»

37 « lui qui avait été si beau... démis, brisé, défait... et ce sang déjà coagulé sur sa tempe...[...] il a dû sauter de la fenêtre de sa chambre, il s'est écrasé sur le sol...»

38 "Cet homme n'est pas Don Juan. Cet homme est un imposteur. »

39 «Don Juan n'est pas soumis aux lois du temps.» 
4. Уместо закључка

Дакле, многобројне Шмитове реминисценције које смо поменули истичу молијеровско наслеђе које је присутно у комаду Ноћ у Валоюи, али је све остало различито. Можемо рећи да је, на тај начин, Шмитов комад у непрестаном дијалогу и полемици са Молијеровим комадом.

Ни тема суђења, по чијој је интерпретацији Шмитов комад потпуно оригиналан, није сасвим нова у великој породици верзија овог мита. Она се први пут појављује код Едмона Ростана (Édmond Rostand) 1921. године. Осим речи ноћ, која се појављује у наслову оба комада, и друге референце код Шмита упућују на Ростанов комад Последња Дон Жуанова ноћ (La Dernière Nuit de Don Juan), у ком је главни јунак такође имао улогу оптуженика. У овој „драмској поеми“40 (ROSTAN 1921: 8) Дон Жуан се налази пред Каменом статуом, Ђаволом и „хиљаду и три сенке“41 (ROSTAN 1921: 11) жена које је завео, а које долазе из прошлости како би му пресудиле и осветиле се. И код Шмита се помињу „хиљаду и три Шпањолке“42 (ŠMIT 2009: I, 5, 33) наспрам свега сто Францускиња које је, према Зганареловој бележници, Дон Жуан завео. Такође, у оба комада се појављују сцене позоришта у позоришту, уз помоћ којих се приказују догађаји из прошлости. Али код Шмита се са божанског суда и божје казне прелази на један сасвим конкретан и лаички суд, састављен искључиво од жена.

Најзад, бројне су и референце које упућују на Моцартову оперу, односно на Да Понтеов либрето. Говорећи о утицајима у интервјуу са Пјером Бринелом, Шмит наводи да је његово писање „веома потхрањено музиком и опером“, па тако у комаду Ноћ у Валоюи „постоји женски трио у првом чину, велики ноћни дуо у другом, а трећи чин је скерцо у рондоу“, али и „промена тонова, ритмова, расположења такође одговарају музичким потребама“"43 (BRINEL 2009: 146).

Све наведено чини од прве Шмитове драме снажан отворен текст, чији су интертекстуални домети велики, а чије теме, бриљантан дијалог и неочекивани обрти наговештавају његов будући велики успех у позоришту.

\footnotetext{
40 "poème dramatique "

41 "les mille et trois ombres"

42 " mille et trois Espagnoles»

43 « Mon écriture est très nourrie de musique et d’opéra. Aussi dans La Nuit de Valognes y a-t-il un trio de femmes au premier acte, un grand duo nocturne au deuxième, un troisième acte scherzo en rondo. Mais changement de tons, de rythme, d'humeurs, correspondent aussi à des nécessités musicales. "
} 


\section{Цитирана литература}

BJELIĆ 2009: BJELIĆ, Nikola. « Transformation du mythe de Don Juan dans La Nuit de Valognes d'Éric-Emmanuel Schmitt». Filološki pregled, god. 36, sv. 2 (2009): str. 83-89. Beograd: Filološki fakultet.

BJELIĆ 2016a: BJELIĆ, Nikola. „Uvod u dramsko delo Erik-Emanuela Šmita“. U: Kod 21, god. 2, sv. 2 (2016): str. 7-21. Šabac: Šabačko pozorište. [orig.] БЈЕЛИЋ, Никола. „Увод у драмско дело Ерик-Емануела Шмита“. Код 21, год. 2, св. 2 (2016): стр. 7-21. Шабац: Шабачко позориште.

BJELIĆ 2016b: BJELIĆ, Nikola. „Rasprava o slobodi i moralu u komadu Liberten Erik-

Emanuela Šmita“. Zbornik Matice srpske za književnost i jezik, god. 64, sv. 1 (2016): str. 175-190. Novi Sad: Matica srpska. [orig.] БЈЕЛИЋ, Никола. „Расправа о слободи и моралу у комаду Либертен Ерик-Емануела Шмита“. Зборник Матице српске за книжевност и језик, год. 64, св. 1 (2016): стр. 175-190. Нови Сад: Матица српска.

BJELIĆ 2016c: BJELIĆ, Nikola. „Erik-Emanuel Šmit i muzika: drama Zagonetne varijacije“. Rock'n'Roll, Zbornik radova sa naučne konferencije Srpski jezik, književnost, umetnost, knjiga 2 (2016): str. 215-223. Kragujevac: FILUM. [orig.] БЈЕЛИЋ, Никола. „Ерик-Емануел Шмит и музика: драма Загонетне варијације“. Rock'n'Roll, Зборник радова са научне конференције Српски језик, књижевност, уметност, књига 2 (2016): стр. 215-223. Крагујевац: ФИЛУМ.

BRINEL 2009: BRUNEL, Pierre. "Interview avec Éric-Emmanuel Schmitt». In : SCHMITT, Éric-Emmanuel. La Nuit de Valognes. Paris : Magnard, 2009, str. $145-150$.

DELENBAH 1977: DÄLLENBACH, Lucien. Le récit spéculaire. Essai sur la mise en abyme. Paris : Seuil, 1977.

DOLEŽEL 2008: DOLEŽEL, Lubomir. Heterokosmika: fikcija i mogući svetovi. Prevela Snežana Kalinić. Beograd: Službeni glasnik, 2008.

GURNE 2013a: GOURNAY, Aurélia. Don Juan en France au XXe siècle: réécritures d'un mythe. Doktorska dis. Université Sorbonne nouvelle - Paris 3, 2013. $<$ https://tel.archives-ouvertes.fr/file/index/docid/975274/filename/2013PA030081. pdf $>23.3 .2021$.

GURNE 2013b: GOURNAY, Aurélia. «Les Don Juan français contemporains : de la crise du héros à celle de l'écriture ». Voix plurielles, 10, 2 (2013) : 257-269. $<$ https://doi.org/10.26522/vp.v10i2.863> 24.3.2021.

LAMEZON 2006: LAMAISON, Sophie. Étude sur La Nuit de Valognes. Paris : Ellipses, 2006.

MILAČIĆ 1973: MILAČIĆ, Dušan. Večni Molijer. Beograd: Slovo ljubve, 1973. [orig.] МИЛАЧИЋ, Душан. Вечни Молијер. Београд: Слово љубве, 1973.

MIOČINOVIĆ 2008: MIOČINOVIĆ, Mirjana. Pozorište i giljotina. Rasprave o drami. Beograd: Fabrika knjiga, 2008.

RUBIN 2006: ROUBINE, Jean-Jacques. Introduction aux grandes théories du théâtre. Paris : Armand Colin, 2006.

RUSE 1995: RUSE, Žan. Mit o Don Žuanu. Prevela Jelena Novaković. Sremski Kar- 
lovci, Novi Sad: Izdavačka knjižarnica Zorana Stojanovića, 1995. [orig.] РУСЕ, Жан. Мит о Дон Жуану. Превела Јелена Новаковић. Сремски Карловци, Нови Сад: Издавачка књижарница Зорана Стојановића, 1995.

RUSE 1998: RUSE, Žan. Književnost baroknog doba u Francuskoj. Kirka i Paun. Prevela Tamara Valčić Bulić. Sremski Karlovci, Novi Sad: Izdavačka knjižarnica Zorana Stojanovića, 1998.

ŠMIT 2005: SCHMITT, Éric-Emmanuel. „Ma première pièce....”. 16 novembre 2005. $<$ https://www.eric-emmanuel-schmitt.com/Theatre-La-nuit-de-valognes. html> 20.3.2021.

\section{Извори}

MOLIJER 1975a: MOLIÈRE. Dom Juan ou le festin de pierre. In : MOLIÈRE. Euvres complètes. Paris : Seuil, 1975, str. 285-310.

MOLIJER 1975b: MOLIÈRE. La Critique de l'École des femmes. In : MOLIÈRE. Euvres complètes. Paris : Seuil, 1975, str. 199-212.

MOLIJER 1976: MOLIJER. Don Žuan. Preveo Mladen Leskovac. Beograd: Rad, 1976. MOLIJER 1993: MOLIJER. Don Žuan. Preveo Danilo Kiš. Beograd: Lapis, 1993.

MOLINA 2000: MOLINA, Tirso de. Seviljski zavodnik i kameni gost. Prevod, predgovor i komentari Aleksandra Mančić-Milić. Beograd: Rad, 2000.

ŠMIT 2006: SCHMITT, Éric-Emmanuel. Théâtre 1. Paris : Albin Michel, 2006.

ŠMIT 2009: SCHMITT, Éric-Emmanuel. La Nuit de Valognes. Paris : Magnard, 2009. ROSTAN 1921: ROSTAND, Édmond. La Dernière Nuit de Don Juan. Paris : Librairie Charpentier et Fasquelle, 1921. <ftp://ftp.bnf.fr/011/N0113119_PDF_1_1DM.pdf> 21.3.2021.

Nikola Bjelić

\section{LES RELATIONS INTERTEXTUELLES ENTRE LA NUIT DE VALOGNES D'ÉRIC-EMMANUEL SCHMITT ET DOM JUAN DE MOLIËRE}

Dans cet article, nous traitons de la figure mythique moderne la plus célèbre, Don Juan, dans la première pièce de lécrivain français contemporain Éric-Emmanuel Schmitt, La Nuit de Valognes, écrite en 1989. Le but de cet article est de montrer la transformation de ce héros dans la réécriture de Schmitt de ce mythe créé au baroque. À travers une lecture intertextuelle de la pièce de Schmitt avec celle, la plus célèbre, de Molière (Dom Juan, 1665), nous avons montré quels sont les points de contact et quelles sont les différences entre ces deux textes dramatiques. Nous avons essayé de prouver la thèse selon laquelle la pièce de Schmitt est plus classique que celle de Molière, qui, par ses caractéristiques, appartient plutôt à la poétique baroque. Nous avons aussi mentionné les relations de la pièce de Schmitt avec quelques réinterprétations récentes de ce mythe.

Mots-clés : Molière, Schmitt, Don Juan, classicisme, trois unités, mythe, réécriture, intertextualité. 